\title{
STRATEGIES FOR EFFECTIVE TEACHING OF READING AMONG SECONDARY SCHOOLS IN MORO LOCAL GOVERNMENT AREA OF KWARA STATE.
}

Kolawole Saliu

Department of General Studies Education

Kwara State College of Education (Technical),

Lafiagi, P. M. B 01 Lafiagi, Kwara State, Nigeria.

Kolawolesaliu123@gmail.com

\begin{abstract}
Learning a language is different from acquiring it. To learn a language, all necessary skills are required. However, reading, a receptive skill, remains one of those four skills needed for language learning. As teachers of English, all efforts must be put forward in order to improve the teaching of reading through required strategies for effective teaching. This study however centers on effective teaching strategies of reading among secondary schools in Moro Local Government Area of Kwara State. In order to achieve this, questionnaire was used to elicit information on the respondents so as to be able to gather all necessary information needed for this study. The sample consists of Sixty (60) English language teachers who were randomly selected across twenty (20) randomly selected Junior and senior secondary schools in Moro Local Government Area of Kwara State. Data were analysed using descriptive and correlation statistics. The findings of the study revealed that the use of flash-cards, passage of relevant pictures and photographs, among others, are the teaching strategies needed for effective teaching of reading. Based on the result of the findings, it was recommended that sufficient teaching materials should be provided by government to assist teachers in the teaching of reading. This, among others, were discussed in this study.
\end{abstract}

\section{Keywords}

Reading, Strategies, Pre-reading, During reading, Post-reading, Teaching, Reading processes, Comprehension, Knowledge, Skills. 


\section{INTRODUCTION}

Reading is a receptive skill of language learning. It involves the ability to seeing and interpreting symbols (Kolawole, 2017). The word 'reading' requires that leaners should read and interpret a printed material or text.

In Nigeria, it is evident that almost all the learners of English are second language learners where they have acquired the first language. In the light of this, their reading ability has been affected very seriously. Very many students have like-warm attitudes to reading as teachers also need to adopt necessary strategies needed for its teaching so as to have better teaching of reading and accurate reading output from the students.

Teachers teach under unconductive atmosphere/environment; the teaching of reading also takes place in the wee hours of the day when students have become very weak. It has also been observed that students are disallowed from reading aloud; teachers seemto dominate the reading exercise while students remain passive during the lesson; suitable passages are far from what the teachers read in class. All these amount to the exigency of this study since reading is a means of developing an individual. Anieze (2011) right observes that:

The imperativeness of good strategies of teaching reading follows that teachers are accountable for methodologies to be adopted towards improving reading exercise of the learners..... time, materials and age counts so much in what is being read. Teachers as the custodians of teaching, must equally take the cognizance of experience and 
environment in the choice of text in order to avoid effort-in-futility and utter fiasco.

\section{Research Questions}

In order to guide the study, the following research questions were raised:

i. What are the effective strategies for the teaching of reading among Secondary Schools in Moro Local Government Area of Kwara State?

ii. Do teachers' methods of teaching affect the teaching of reading among Secondary Schools in Moro Local Government Area of Kwara State?

iii. Are there enough materials (textbooks) for the teaching of reading among Secondary Schools in Moro Local Government area Kwara State?

\section{Research Hypotheses}

The following hypotheses were formulated to guide the study.

Hi: The teaching of reading requires no strategies among Secondary Schools in Moro Local Government Area of Kwara State.

Hii: Teachers' methods of teaching affects the teaching of reading among Secondary Schools in Moro Local Government Area of Kwara State.

Hiii: There are enough material for the teaching of reading among Secondary Schools in Moro Local Government Area Kwara State. 


\section{LITERATURE REVIEW}

People have different views on the word reading. This indicates that it means different things to different people. The LongmanActive Study Dictionary (1998) defines reading as "the activity of looking at and understanding written words". This implies that reading involves an activity to peep through and understand a given text.

Bankole (2014) believes that "reading is a skill that involves a number of more general or lesser skills"(p.29). In his opinion, three of these skills assist the readers to understand what the passage is all about. He emphasizes that reader's ability to usually decipher or recognize the stylized shape or figures of ink makes on a page. He reiterates further that at this level, reading includes mechanical movement of the eye from the left to the right while the brain receives signals from the eye. Secondly, the reader needs the ability to correlate the patterned stylized shapes or ink marks on paper with language which the reader can understand better. Finally, he concludes that, cognition plays an effective role towards understanding of a passage or text.

Olajide (2009) defines reading as "an interaction between the author and the reader" (p.43). Kolawole (2017) stresses that for a reader to be able to read and comprehend expectedly, noise, concentration, time and availability of materials remain the constraints for effective and efficient reading. He later accounts for eye movement, visual span, and selective reading, among others, as the techniques or strategies of reading.

Iliyas (2002) defines reading as "an active process of constructing meaning from text". In a similar vein, Lawal (2003) considers reading as a process by which an individual attains understanding, or scoop meaning by means of interesting with a text while Bello (2004) asserts that reading can be 
seen as a dialogue or exchange of information between interlocutors (the author and the reader) through the medium of print.

According Iliyas (2002) (as cited in Olaofe,1997), observes that in the process of requiring/cultivating the right reading comprehension skills, several inhibitions are observed to have been responsible for minimal and partial understanding which include: misunderstanding, misinterpretation, ambiguity confusion and message abandon. Iliyas (2002) further stresses that the English Language teachers are not only saddled with the responsibility of teaching the grammar, phonemes and writing skills, but to professionally instill healthy reading habits and identify reading inhibitions in their students. In their submission, Torgenshen and Hayes (2005) opine that in order to achieve these, the teacher should make use of his/her intuition, experiences and common sense.

Parlindungan (2010) in a swift reaction to the importance and significance of teaching and learning of reading, accounts for three main theories. These are; the traditional theory, or bottom up processing, which focuses on the printed form of a text, the cognitive view, or top-down processing which enhances the role of background knowledge in addition to what appears on the printed page and meta cognitive view which is based on the control and manipulation that a reader can have on the act of comprehending a text, and thus, emphasises the involvement of the reader's thinking about what he is doing while reading. According to him, there are three consecutive stages for implementing the aforementioned theories in order to assist learner's abilities during reading and teacher's effeciveness during teaching. They are often seen as guidelines for effective teaching of reading (Parlindungan, 2010). 
The first is the pre-reading tips which emphasizes that before the actual act of reading a text begins, some points should be regarded in order to make the process of reading more comprehensible. More importantly, the teachers need to make sure that the texts to be read contain words and grammatical structures familiar to the learners for if the text contains unfamiliar vocabulary, teachers can introduce key vocabulary in pre-reading activities that focus on language awareness, such as finding synonym, antonym, derivatives, or associated words. He stresses further that teachers should make sure that the topics of texts chosen are in accordance with the age range, interests, sex and background culture of the students for whom they are intended in order to enhance students' comprehension (Parlindungan, 2010).

According to him, activities that are involved during pre-reading stage include teacher-directed, pre-reading where some key vocabulary, ideas in the text, and the types of the text are explained. In this approach, the teacher directly explains the information the students will need, including key concepts, important vocabulary etc. The text types are also necessary to introduce because texts may take on different forms and hold certain pieces of information in different places. This will assist to develop their understanding of the layout of the materials. Other activities include interactive activities in which the teacher leads a discussion which he/she draws out the information students already have and interjects additional information deemed necessary to an understanding of the text to be read. The least of the activities remains reflective activities in which students are guided to make themselves aware of the purpose and goal for reading certain piece of written material. The students may be guided to ask themselves 
"why am I reading this text? What do I want to do or know after finish reading?

The second stage, 'during-reading tips', consists of activities like taking notes, reaching, predicting, selecting significant information, making selections, integrating prior knowledge, skipping significant parts, re-reading, making use of context or guessing, pausing, making use of context or guessing, breaking words into component parts, paraphrasing and monitoring (Parlindungan, 2010). The third stage which remains the final stage is 'after-reading tips'. This is basically depend on the purpose of reading and the type of information extracted from the text. Barnett (1988) asserts that 'post-reading exercise first check students' comprehension and then lead students to deeper analysis of the text; He further emphasizes that the purpose of reading is not to memorize an author's point of view or to summarize text content, but rather to see into another mind, or to engage new information with what one already knows.

These three stages also agree with Daniel and Zelman (2004). According to them 'pre-reading' is referred to as 'before readings skills' which encompasses the following:

i. Previewing/surveying-scan pictures, titles and subtitles

ii. Text Analysis-identify text format and select proper reading strategies based on the type and genre of the text.

iii. Elicit prior knowledge:-fast experiences used to make connections while reading.

iv. Develop a purpose for reading by making questions and predictions based upon the preview of the text. 
In their opinion, all these will allow the readers to read at the appropriate time and rate. Not only this, it will help them move information from the sensory register into their working (short-term) memory. During reading skills, teachers need to update and create new predictions and questions to maintain focus while actively reading; work to expand vocabulary skills and adjust reading rate based on the difficulty of the text and personal reading skills; using information from both the text and prior knowledge to create and maintain a mental image (visualization) and develop links between the text and prior knowledge to ensure comprehension, monitoring, re-reading and context clues are equally stressed (Daniels \& Zemelman, 2004; Oczkus, 2004; Ormond, 2006; Robb, 2000; and Wilson, 2004).

During reading skills according to them will help the reader to stop reading passively and begin to become an active reader. After reading skills involve assess reading comprehension, summarize, synthesize and evaluate. This will allow readers/students to know how meaningful learning experiences will occur and equally have reader's chance of retrieving the information. These stages are presented in Ormond's diagram below. 


\section{Figure I}

\section{Building Comprehension: A Model of Human Memory}

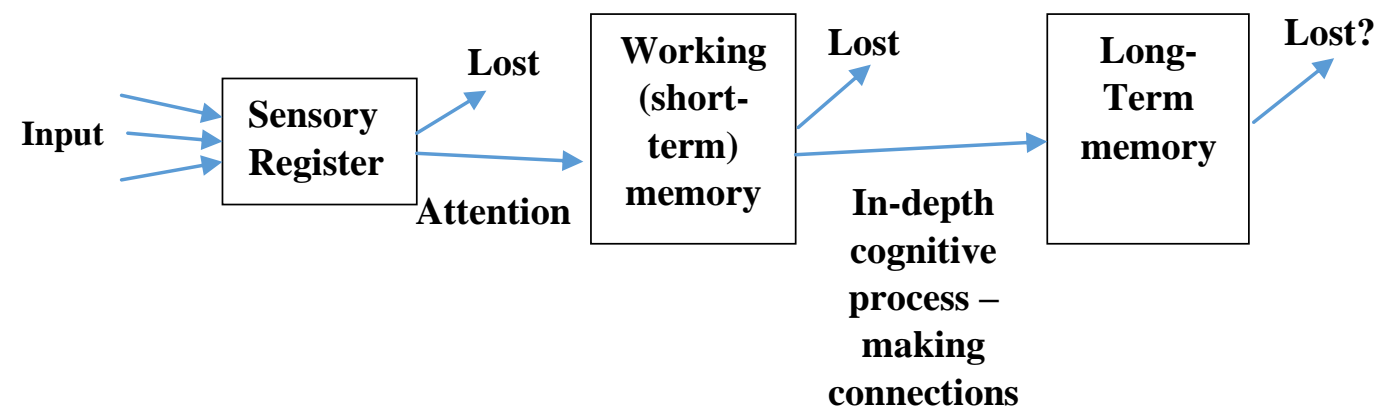

Source: Ormond, J. (2006). Essential of Educational Psychology

Table I

The Reading Processes

\begin{tabular}{|lr|l|l|}
\hline \multicolumn{2}{|c|}{ Before } & \multicolumn{1}{|c|}{ During } & \multicolumn{1}{c|}{ After } \\
\hline Preview/surveying & Test & Update Questions \& & Assesses \\
Analysis Elicit $\quad$ Prior & Predictions & Comprehension \\
Knowledge & & & \\
Questions & & Visualise & Summarise \\
Predictions & & Connections & Synthesise \\
Purpose of Reading & & Monitor comprehension & Evaluate \\
& & Apply & \\
\hline
\end{tabular}

Theoretical Framework

The theoretical framework of this study hinged on Parlindungan (2010) theories of teaching and learning reading. These are the traditional 
theory or bottom up processing, which focuses on the printed form of al text, the cognitive view, or top down processing which enhances the role of background knowledge in addition to what appear on the printed page and meta-cognitive view which is based on the control and manipulation that a reader can have on the act of comprehending a text, and thus, emphasizes the movement of reader's thinking about what he is doing while reading.

In connection with these three main theories, he further accounts for three consecutive stages which assist learner's abilities during reading and teacher's effectiveness during teaching. They are often regarded as the guidelines for effective teaching of reading. The first one relies on prereading tips which emphasizes that before the actual act of reading a text begins, some points should be regarded in order to make the process of reading more comprehensible. More importantly, the teachers need to make sure that texts to be read contain words and grammatical structures familiar to the learners for if the text contains unfamiliar vocabulary, teachers can introduce key vocabulary in pre-reading activities.

Activities involved in pre-reading stage include teacher-directed, rereading stage where some key vocabulary, ideas in the text, and the types of the texts are explained. This approach allows the teachers to explain the information which students will need including key concepts, important vocabulary etc (Parlindungan, 2010). The second stage is "during-reading tips which consists of activities like taking notes, reaching, predicting, selecting significant part, re-reading, making use of context or guessing etc. the third stage which is known as the final stage is known as 'after reading tips'. It is basically depend on the purpose of reading and the type of information extracted from the text. These three stages are also in line with Barnett (1988); Daniel and Zelman (2004). The diagram of Ormond (2006) contained 
in the overview of reading also captures the three stages of reading which were later expanded by Parlindungan (2010). These activities were used to drawn up the questionnaire used for data analysis.

\section{RESEARCH METHOD}

This study is a descriptive research. Strategies for effective teaching of reading among secondary schools (SFETRASS) questionnaire was used to elicit information on the respondents in order to be able to gather necessary data needed for this study. The questionnaire used for the study consists of twenty (20) items. These items are in form of statements prepared in four multiple options ranging from SA (strongly Agreed,) A (Agreed), SD (Strongly Disagreed) to D which indicates Disagreed.

A total number of twenty (20) junior and senior secondary schools were randomly selected across five districts of Moro Local Government Area of Kwara State. In each district, four (4) secondary schools were involved (both junior and senior). This justifies equal representation of the schools across all the districts of the Local Government (Moro). The sample of this study consists of sixty (60) English Language teachers including male and female. Three (3) English teachers were randomly selected in each of the randomly selected junior and senior secondary schools in order to have adequate and equal representation of respondents (English teachers). This agrees with Osuala (1982) who is of the opinion that "random sampling is that method of drawing a portion (or sample) of population or universe so that each member of the population or universe has an equal chance of being selected or represented". In a random sampling, all possible samples of fixed size (or other factors) have the same probability of being selected. A sample drawn at random is unbiased in the sense that no members of the population 
has any more chance of being selected that any other member (Osuala, 1982).

\section{Data Analysis and Presentation of Results}

This aspect deals with analysis of data and presentation of result. These are considered under the following sub-headings:

\section{Treatment of Research Questions.}

Items on the questionnaire were used to treat the research questions earlier raised in this study. Descriptive statistics was used for the analysis of research questions. As soon as data were collected, frequency count of the number of respondents were converted to percentages. This forms part of the basis for data analysis.

RQ 1: What are the effective strategies for the teaching of reading among secondary schools in Moro Local Government, Kwara State?

Items $1,2,3,5,14,15,17,19$ and 20 were used to treat this research question.

\section{Table II}

Effective Strategies for Teaching of Reading among Secondary Schools in Moro Local Government, Kwara State.

\begin{tabular}{|l|l|l|l|l|l|}
\hline S/No & \multicolumn{1}{|c|}{ Item } & \multicolumn{3}{|c|}{ Responses } \\
\hline & & \multicolumn{1}{|c|}{$\begin{array}{c}\text { Positive } \\
(\%)\end{array}$} & $\begin{array}{c}\text { Negative } \\
(\%)\end{array}$ \\
\hline 1 & $\begin{array}{l}\text { Questioning students arouse their interest } \\
\text { before the text is read. }\end{array}$ & $75 \%$ & 15 & $25 \%$ \\
\hline 2 & The use of flash-cards enhances effective & 50 & $83 \%$ & 10 & $17 \%$ \\
\hline
\end{tabular}




\begin{tabular}{|l|l|l|l|l|l|}
\hline & teaching of reading. & & & & \\
\hline 3 & $\begin{array}{l}\text { I don't always read the text before my } \\
\text { students. }\end{array}$ & 72 & 18 & $30 \%$ \\
\hline 4 & $\begin{array}{l}\text { Only few students are always called to read } \\
\text { in my class. }\end{array}$ & 52 & $87 \%$ & 8 & $13 \%$ \\
\hline 5 & $\begin{array}{l}\text { All the rules governing reading a text } \\
\text { should be discarded }\end{array}$ & $23 \%$ & 46 & 775 \\
\hline 6 & $\begin{array}{l}\text { Students should remain passive while } \\
\text { teaching reading. }\end{array}$ & $20 \%$ & 48 & $80 \%$ \\
\hline 7 & $\begin{array}{l}\text { Text/passage of relevant pictures and } \\
\text { photographs are good for teaching reading. }\end{array}$ & 48 & $80 \%$ & 12 & $20 \%$ \\
\hline 8 & $\begin{array}{l}\text { Familiar/related words should be introduced } \\
\text { by teachers before reading begins. }\end{array}$ & $92 \%$ & 5 & $8 \%$ \\
\hline 9 & \begin{tabular}{l} 
I prefer teaching reading in the afternoon \\
\hline
\end{tabular} & 40 & $67 \%$ & 20 & $33 \%$ \\
\hline
\end{tabular}

Table II indicated teachers' response at the level of positive and negative attitude. It has been observed from their responses that the teaching of reading attracts some strategies which will allow the teachers to teach it adequately, well. The teachers' responses have clearly confirmed this submission.

RQ 2: Do teachers' methods of teaching affect the teaching of reading among secondary schools in Moro LGA, Kwara State?

Items $4,6,7,8,10,11,13$ and 18 on the questionnaire were used to answer this research question. 


\section{Table III}

Teachers' Methods of Teaching Reading Among Secondary Schools in Moro Local Government, Kwara State

\begin{tabular}{|l|l|l|l|l|l|}
\hline S/No & \multicolumn{1}{|c|}{ Item } & \multicolumn{3}{c|}{ Responses } \\
\hline & \multicolumn{3}{|c|}{$\begin{array}{c}\text { Positive } \\
(\%)\end{array}$} & \multicolumn{2}{|c|}{$\begin{array}{c}\text { Negative } \\
(\%)\end{array}$} \\
\hline 10 & $\begin{array}{l}\text { I leave difficult words for my students to } \\
\text { pronounce }\end{array}$ & 48 & $80 \%$ & 12 & $20 \%$ \\
\hline 11 & $\begin{array}{l}\text { As teacher of English, I jesttison re-reasing } \\
\text { exercise }\end{array}$ & 41 & $68 \%$ & 19 & $32 \%$ \\
\hline 12 & I encourage silent reading in my class & 54 & $90 \%$ & 6 & $10 \%$ \\
\hline 13 & In my class, any text is read & 50 & $83 \%$ & 10 & $17 \%$ \\
\hline 14 & $\begin{array}{l}\text { Students' interest needs not to be considered } \\
\text { in reading a text }\end{array}$ & 4 & $7 \%$ & 56 & $93 \%$ \\
\hline 15 & $\begin{array}{l}\text { I prefer a text or passage with a more } \\
\text { difficult and elevated language }\end{array}$ & 46 & $77 \%$ & 14 & $23 \%$ \\
\hline 16 & $\begin{array}{l}\text { My students need no explanation on the text } \\
\text { being read }\end{array}$ & 8 & $13 \%$ & 52 & $87 \%$ \\
\hline 17 & Students' evaluation needs not after reading & 13 & $22 \%$ & 47 & $78 \%$ \\
\hline 18 & $\begin{array}{l}\text { Any text/passage is meant to renew } \\
\text { students' previous knowledge }\end{array}$ & $95 \%$ & 3 & $5 \%$ \\
\hline
\end{tabular}

Table III gave clear indications of teachers' responsesin connection with objectives of this study. Their responses have confirmed that teachers' methods of teaching greatly affect the teaching of reading among secondary schools in Moro Local Government Area of Kwara State. 
RQ 3: Are there enough materials for teaching reading among secondary schools in Moro Local Government Area, Kwara State?

Items 9 and 12 are used to answer this way research question.

Table IV

Availability of Materials for Teaching Readingamong Schools in Moro Local Government Area, Kwara State.

\begin{tabular}{|l|l|l|l|l|l|}
\hline S/No & \multicolumn{1}{|c|}{ Item } & \multicolumn{4}{|c|}{ Responses } \\
\hline & \multicolumn{1}{|c|}{\begin{tabular}{c}
\multicolumn{1}{|c|}{ Positive } \\
$(\%)$
\end{tabular}} & $\begin{array}{l}\text { Negative } \\
(\%)\end{array}$ \\
\hline 19 & $\begin{array}{l}\text { I don't consider my students in the choice of } \\
\text { text to be read in class. }\end{array}$ & 53 & $88 \%$ & 7 & $12 \%$ \\
\hline 20 & $\begin{array}{l}\text { I am not bothered when my students have } \\
\text { no text books while teaching reading in my } \\
\text { class }\end{array}$ & 49 & $82 \%$ & 11 & $18 \%$ \\
\hline
\end{tabular}

Teachers' responses as indicated from the above tables have shown their extent of agreement and disagreement. Based on their responses, it has been established that there are no enough materials for the teaching of reading among secondary school schools in Moro Local Government of Kwara State.

\section{Testing Of Research Hypothesis}

The hypotheses earlier formulated in this study were tested using correlation statistics at the level of significance of 0.05

Hypothesis one: The teaching of reading among secondaryschools in Moro Local Government Area Kwara state requires no strategies 


\section{Table V}

Teachers' Strategies of Teaching Reading among Secondary Schools in Moro Local Government Area, Kwara State.

\begin{tabular}{|c|c|c|c|c|c|c|c|c|}
\hline $\mathrm{V}$ a $\mathrm{r}$ i a b l e s & $\mathrm{N}$ & $X$ & S D & D F & $\begin{array}{l}\mathrm{p}- \\
\text { Value }\end{array}$ & $\begin{array}{ll}\mathrm{r} & - \\
\mathrm{c} & \mathrm{a}\end{array}$ & r-tab & Remark \\
\hline \multirow{2}{*}{$\begin{array}{l}\text { Teachers' strategies of } \\
\text { Teaching reading }\end{array}$} & 60 & 2.01 & 1.55 & 198 & 0.00 & 0.087 & 0.153 & \multirow{4}{*}{$\begin{array}{l}\mathrm{H} \\
\text { Rejected }\end{array}$} \\
\hline & & & & & & & & \\
\hline \multirow{2}{*}{$\begin{array}{l}\text { Students' reading } \\
\text { P r ofi c i e n c y }\end{array}$} & 60 & & & & & & & \\
\hline & & & & & & & & \\
\hline
\end{tabular}

Table $\mathrm{V}$ showed that the $\mathrm{p}$-value of 0.00 is less than the level of significant of 0.05. The hypothesis one which stated that the teaching of reading among secondary schools in Moro Local Government Area requires no strategies is rejected. Thus, the teaching of reading requires some strategies in order to allow the teacher to teach it very well so as to assist students to improve their reading skill.

Hypothesis Two: Teachers' methods of teaching affects the teaching of reading among secondary schools in Moro Local Government Area of Kwara State. 
Table VI

Teachers' Methods of Teaching Reading among Secondary Schools in Moro Local Government Area, Kwara State.

\begin{tabular}{|l|l|l|l|l|l|l|l|l|}
\hline Variables & $\mathrm{N}$ & $\mathrm{X}$ & $\mathrm{SD}$ & $\mathrm{DF}$ & $\mathrm{p}-$ & $\mathrm{r}$-cal & r-tab & Remark \\
value & & & & & & \\
\hline $\begin{array}{l}\text { Teacher' } \\
\text { methods of } \\
\text { teaching reading }\end{array}$ & 60 & 2.84 & 1.99 & 198 & 1.07 & 0.096 & 0.099 & HO \\
\cline { 2 - 8 } & & & & & & & & Accepted \\
\cline { 1 - 7 } $\begin{array}{l}\text { Students' } \\
\text { reading } \\
\text { Proficiency }\end{array}$ & 60 & & & & & & & \\
\cline { 2 - 8 } & & & & & & & & \\
\hline
\end{tabular}

Table VI indicated that the calculated p-value of 1.07 is greater than the level of significant of 0.05. The hypothesis two which stated that teachers' methods of teaching affects the teaching of reading among secondary schools in Moro Local Government Area is accepted. Thus, teachers' methods of teaching actually affect the teaching of reading

Hypothesis Three: There are enough materials for the teaching of reading among secondary schools in Moro Local Government area of Kwara State. 
Table VII

Availability of Materials for the Teaching of Reading among Secondary Schools in Moro Local Government Area of Kwara State.

\begin{tabular}{|l|l|l|l|l|l|l|l|l|l|}
\hline S/NO & Variables & N & X & SD & DF & $\begin{array}{l}\text { P- } \\
\text { value }\end{array}$ & r-cal & v-tab & Remark \\
\hline $\begin{array}{l}\text { Availability } \\
\text { of } \\
\text { materials } \\
\text { for the } \\
\text { teaching of } \\
\text { reading }\end{array}$ & 60 & 2.01 & 1.55 & 198 & 0.00 & 0.087 & 0.153 & $\begin{array}{l}\text { HO } \\
\text { Rejected }\end{array}$ \\
\hline $\begin{array}{l}\text { Students' } \\
\text { reading } \\
\text { proficiency }\end{array}$ & & & & & & & & \\
\hline
\end{tabular}

Table VII has shown that the p-value of 0.00 is less than the level of significance of 0.05 . The hypothesis three which stated that there are enough materials for the teaching of reading among secondary schools in Moro Local Government Area of Kwara State is rejected. Thus, there are no enough teaching materials for the teaching of reading among secondary schools in Moro Local Government Area of kwara state.

\section{FINDINGS AND DISCUSSION}

The research questions were treated and examined through teacher's responses. These have been indicated in tables 1, 2 and 3. Table 1 remains a reflection of teachers' responses in relation to the effective teaching strategies involved in the teaching of reading among Secondary Schools in Moro Local 
Government Area of Kwara State. They (teaches) agreed that the teaching of reading attracts some strategies in order to allow the teachers to deliver very well. For instance, $50(83 \%)$ agreed that the use of flesh-cards as a strategy for teaching reading enhances effective teaching of reading while $10(17 \%)$ disagreed with the proposition. Also $48(80 \%)$ of the teaches supported the proposition that text or passage of relevant pictures and photographs are good for teaching reading while $12(20 \%)$ disagreed with the assertion. These, and many other responses of teachers attest to effective use of teaching strategies for effective teaching of reading. The result agreed with Ajayi (2008) who is of the view that the teaching of reading requires certain techniques which teachers need to know for proper and adequate teaching of reading.

Table 2 reveals teacher's responses on the teaching methods required for teaching reading. $41(68 \%)$ of teachers agreed with re-reading exercise while teaching reading while $19(32 \%)$ disagreed with the proposition. Similarly, 54 (90\%) supported silent reading as a method for teaching reading while $6(10 \%)$ of teachers showed negative responses. From all indications, the result of table 2 has shown that teachers' methods of teaching greatly affect the teaching of reading. Teachers are implored to always employ rereading exercise among others as a suitable method for teaching reading. The result from table 3 indicated that there are no enough materials for the teaching of reading among Secondary Schools in Moro Local Government Area of Kwara State.

The hypotheses earlier formulated in this study were equally tested. Hypothesis one revealed that the teaching of reading requires some strategies in order for the teachers be able to handle the teaching of reading very well. Olatunji (2006) opined that it is hard to disregard or separate teaching 
techniques from the teaching of reading; teachers' strategies also count on the effectiveness of teaching reading. Hypothesis two revealed that teacher's methods of teaching affect the teaching of reading among Secondary Schools in Moro Local Government Area of Kwara State. Anthony (2004) observed that "every teacher is adjuged by the output of what he teaches". This justifies the significance of teachers' methods of teaching in the teaching of reading. Finally, hypothesis three also revealed that there are no enough materials for the teaching of reading among Secondary Schools in Moro Local Government Area of Kwara State. Moore (1992) argued that if reading materials are readily available, it will allow the teachers to handle their teaching effectively well.

\section{CONCLUSION}

Reading is a language skill that is very essential and important not only at Secondary Schools but across all levels of education. The study is therefore a revelation of effective strategies for the teaching of reading among secondary schools in Moro Local Government Area of Kwara State. Findings of the study have revealed that the teaching of reading requires some strategies while teachers' methods of teaching also count so much on effective teaching of reading. It has also been observed from the findings of the study that there are no enough materials for the teaching of reading. In view of this, government's attention is called to the urgent need of making available all necessary materials needed by teachers for good teaching of reading. 


\section{REFERENCES}

Adam, G. et al. (1998). Longman active study dictionary. Edinburgh: Pearson Education Limited.

Anieze, O.P.(2011). Techniques of teaching reading skill. Benin: CBBTA.

Barnett, M. A.(1998).Teaching reading in a foreign language. ERIC Digest.

Bello, O. (2004). An analysis of Oral Reading and Comprehensive Performance of Junior Secondary School Students in Offa, Kwara State. (Unpublished M.Ed Dissertation). Unilorin .

Daniels, H. and Zemelman, S.(2004). Subject- matter: Every teachers' guide to content area reading. Portsmout :Heineman.

Kolawole, S. Reading and Writing. In Ajibade, L.S. et al. (2007). (eds). Fundamental of English and general studies education. Lafiagi : General Studies Education Department. p. 138

Lawal, R. A. (2003). Reading for Education and Mis-education, $1^{\text {st }}$ in the Eminent Personalities. Lecture series, KWACOED, Oro.

Moore, O.P.(1992).Elements of reading and other language skills. Benin: CBBTA.

Oczkus, L.(2004). Super 6 comprehension strategies: 35 Lessons and more for reading success. Norwood: Christopher - Gordon Publishers.

Olajide S. B. (2009). Types of reading. In Alabi, V.A. and Babatunde, S.T. (eds). The Use of English in higher education.Ilorin: The General Studies Division.p. 43

Olatunji, R.O.(2006).Teaching strategies and methods of reading. Ibadan: UPL.

Ormmond, J. (2006). Essentials of education psychology. Upper Saddle River: Pearson Education Inc.

Osuala, E. C. (1982). Introduction to research methods. Onitsha: AFRICANA FIRST PUBLISHERS Limited.

Parlindungan, P. A.(2010). Review on reading theories and its implication: The teaching of reading. Parlpard 
R. A. Iliyas.(2002). Solving reading problems through the process of diagnosis and remediation. Lafiagi Journal of Education Science and Technology.

Robb. L.(2000). Teaching reading in middle school.New York: Scholastic Professional Books.

Taiwo, S. A. \& Bankole, D. O. (2014).The use of English and general studies for schools and colleges. Ilorin: Abdulrasaq Printing Works.

Tongesen, J. K. and Hayes, L. (2005). Diagnosis of reading difficulties following inadequate performance on state. Retrieved from http:/www/minddisorder.com.

Wilson, E.(2004). Reading at the middle and high school levels: Building action readers across the curriculum. Arlington: Educational Research Service. 